\title{
How the scripts of Latin American screenwriters Lucrecia Martel (Argentina), Anna Muylaert (Brazil) and Claudia Llosa (Peru) have made a mark on the world stage
}

\author{
Margaret McVeigh, Griffith Film School, Griffith University \\ Clarissa Mazon Miranda, Antonio Meneghetti Faculdade
}

\begin{abstract}
The films of Latin American female screenwriters, Lucrecia Martel (Argentina), Anna Muylaert (Brazil) and Claudia Llosa (Peru), have achieved international prominence in recent years. In this article we create new insights into the ways in which these screenwriters have developed scripts for films that have made a mark on the world stage. To this end we will investigate how this acclaim has been enabled by their screenwriting decisions which focus on the creation of women-centered films, as well as their use of the family story as a means of exploring contemporary social and political themes, to tell universal stories which highlight the global in the local. In doing so we canvas the personal, industrial and social factors which have impacted Martel, Muylaert and Llosa's screenwriting careers which have been instrumental in the script development of the films: $L a$ Ciénaga [The Swamp] (Martel, 2001); Que Horas Ela Volta? [The Second Mother] (Muylaert, 2015) and La Teta Asustada [The Milk of Sorrow] (Llosa, 2009). The research for this article is based on personal and media interviews with the writers, as well as contemporary information available only in Spanish and Portuguese, as translated from the original Spanish and Portuguese by Clarissa Miranda.
\end{abstract}

\section{Keywords}

Latin America; Screenwriting; Transcultural, Universal Stories; Martel; Muylaert; Llosa

\section{Latin American female screenwriters on the world stage}

While globally female filmmakers are still under-represented in key creative roles - screenwriter, director and producer - in Latin America there has been an increase in women working in these roles (Benamou and Marsh 2013: 65). The Latin American Female Writer/Directors (Screenwriters who are the Directors of the scripts they have written themselves) - Argentina's Lucrecia Martel, Brazil's Anna Muylaert and Peru's Claudia Llosa - have made a mark on the world stage. They have won critical acclaim by winning major awards and being recognized by their peers by being invited to participate in the world's most prestigious film festivals including Venice and Cannes. For example, in 2010, Peruvian Writer/Director Claudia Llosa's La Teta Asustada [The Milk of 
Sorrow] (2009) was nominated for Best Foreign Language Film, the first Peruvian film to be nominated for this Academy Award. In 2001, Argentinian Writer/Director Lucrecia Martel's La Ciénaga [The Swamp] (2001) was nominated for the Golden Bear (the highest prize awarded for the best film) at the prestigious Berlin International Film Festival.

In this article we argue that the key reasons for the global acclaim they have achieved in their work include their screenwriting decisions around a central female protagonist, their creation of stories rooted in family dynamics, their exploration of social themes which interrogate their respective national, political and cultural realities, and their telling of stories which while local, connect with transnational audiences. To illustrate this discussion, we will consider the following films: Martel's La Ciénaga [The Swamp] (2001), Muylaert's Que Horas Ela Volta? [The Second Mother] (2015) and Llosa's La teta asustada [The Milk of Sorrow] (2009). In common, as stated by Martin and Shaw (2017), these women's writing examples show three aspects: ordinary women and their families (including maternity), specificity of discourse on societies (culture, history), and selfdiscovery as on-going process. As Arendt observes the 'importance of art is in transforming individual lives into politicized lives, lending them a more solid existence through being seen and heard [...] (Arendt in Page 2009: 101-102). So, when we think about the artistic work of Martel, Muylaert and Llosa, it is possible to consider the same question as Punté asks: "what is the mark of a cinema [written and] directed by women and in which measure does this mark serve to change paradigms'? (Punté, 2016: 91). This article tries to answer this question with specific reference to the work of these three writers.

It must be noted that the study of Latin American Female filmmaking is an emerging field and to date, little has been written in English regarding female Latin American Screenwriters. Much of the published work around female filmmakers from Latin America comes out of the Screen Studies and Hispanic Languages arena. In this context we will build on Martin and Shaw's (2017) Latin 
American Women Filmmakers: Production, Politics, Poetics, which provides a broad overview of the industrial and transnational factors that have enabled Latin American female filmmakers to make a "mark on national and transnational circuits" (2017: 15). Shaw and Martin note the symbiotic relationship between politics and aesthetics which forms part of the political heritage of Latin American Cinema with its roots in Third Cinema (2017: 6). Gabriel notes that the political themes of Latin American cinema which draw on the political imperatives of Third Cinema born of the revolutionary Latin American film movements of the 1960's, deal with some of the key themes that we will explore in Martel, Muylaert and Llosa's work: 'Themes of class, race, culture, religion, sex and national integrity [which] are foregrounded, very occasionally in the struggle for the emancipation of women' (Gabriel in Hayward 2000: 391-395).

\section{Telling women-centred stories}

To tell stories, screenwriters draw upon what they know to be true or what they know they want to find out about, including exploring as the kernel for their inspiration, the social, political and cultural facets and reflections of the "truth" they seek from the society and culture they "know". Joanna Page notes in her study of Argentine Cinema, that 'cinema does not occupy a space external to the events that it registers but is very much part of the economic system, the social relations, and the cultural milieu it might be supposed to depict' (2009: 4). Suso D'Amico, one of the screenwriters of the great Italian Neo Realist film, The Bicycle Thief (De Sica, 1948) sought inspiration from the issues facing the people, culture and society that she knew in post-World War II Italy. She notes, 'When I begin, the intention is always to tackle problems of society, then little by little it becomes a private story. I always write about my experience; even in the most fantastical tale there is some autobiographical truth' (D'Amico in McGrath and MacDermott 2003: 162).

\section{The global in the local: family as universal story}

Martin and Shaw note that Latin American female filmmakers' work may be conceived of as 'desire as a force which effects social change, and thus acts as a further site of the political'. They note the 'close relationship between politics and aesthetics which is part of the heritage of Latin American Cinema' and discuss 'ways in which women's filmmaking takes up this aesthetic challenge'. They also note that 'the surge in women's filmmaking across the region has been facilitated by new transnational co-production funding landscapes' (2017: 1). Transnational Film Theory has at its core a focus on what "connects" peoples from across the globe rather than what sets them apart (McVeigh, 2017: 51). To this end we consider the family as a pivotal story scenario that connects people and the way it allows Martel, Muylaert and Llosa to comment on their 
respective culture and society in a transcultural context. In this section we build on Transnational Film theory to use a Transcultural Screenwriting Theory lens, to consider the work of Martel (Argentina), Muylaert (Brazil) and Llosa (Peru) as transcultural storytellers and screenwriters who create films that are both "locally specific", but "universal" and thus "transcultural" and able to connect with global audiences (Brenes, Cattryse and McVeigh, 2019; Yeates, McVeigh and Van Hemert, 2011; McVeigh, 2017).

The three films considered in this article all centre around a family story. The notion of family is a powerful means of connecting with transnational audiences as 'there are basic universal elements that transcend national boundaries: relationships, the individual in society, the influence of politics on the individual, and the family' (Dancyger 2001: 218).

\section{Lucrecia Martel and La Ciénaga}

Shekhar Deshpande and Meta Mazaj note in their book, World Cinema: A Critical Introduction, that filmmaking in Argentina demonstrates the interplay of unique local forces and reflects their place in the global context (2018: 322-328). Lucrecia Martel's La Ciénaga is the story of the family in decay and a powerful exploration of the role of women and the family in a New Argentina shaped and corrupted by an inept patriarchal government. La Ciénaga explores the lost promise of Argentina and issues of class, gender, sexuality and religion in this story of the lives of contrasting families set in a mythical region based on the region of Martel's upbringing, Salta. Indeed, it is the world that Martel knows: 'La Ciénaga is an attempt on the part of its maker to transcend her family history and heal the damage done by the traumas of provincial rearing' (Jubis in Foster 2011: 1). The central character, Mecha, and her family are holidaying at their country house, La Mandragora, a decrepit mansion surrounded by a dense humid forest overshadowed by a towering cloud-covered distant mountain. Oubina notes La Mandragora (The Mandrake) is a plant 'historically used as both an anaesthetic and aphrodisiac' (Oubina 2001: 2) In La Ciénaga 'Martel captures the lassitude, the 
decay, the festering omnipresence of the landscape as both threat and lost potential... the family is pinned down, static, unable to move past the transgressions which will unfold' (McVeigh 2018: 149).

For this research it was not possible to locate a published version of the script for La Ciénaga however it was possible to locate interviews where Martel discusses her process and her vision of the script, particularly in the way the universal thematics of her stories are developed. In $L a$ Ciénaga for example, one of the universal thematics explored is religion. Salta is an extremely religious region of Argentina but paradoxically, at the same time, the region is extremely prejudiced as we see in the Mecha's treatment of her maid. As Martel explains in a video interview (Lim, 2018, video), she, herself, was a catholic activist in her youth. "I though religion could change the world", but now, in her movies, she gives a different perspective of the influence that the universal theme of religion has had in her life. She mentions that the Catholic religion is the system of thought in which she has grown. But, when one realizes that this system does not offers answers anymore, it becomes a sensation of abandonment that is "paralyzing but also rather immense and marvelous" (Oubiña 2015, on-line).

The narrative strands of the elliptical and innovative narrative of this script are set up in the opening sequence where shots of red peppers and cuts to close-ups of the bellies and thighs of the Mecha, and her husband and friends clothed in their bathers. 'They are drinking brightly coloured red drinks. They seem to rise in slow motion to scrape their chairs in unison on the concrete around the pool adding to the ominous off-screen sounds of the thunderstorm and general uneasiness that pervades the scene [...] the pool around which they lounge is a virtual swamp - fetid, dank, green and slimy. It is the central metaphor of the film and the pervading metaphor for their lives - gothic in its darkness, sense of entrapment and the threat of the monstrous' (McVeigh 2018: 149). We see scenes of these drunken adults of the family lying around a fetid pool intercut with scenes of their children running rampant around a swamp wherein, they taunt then shoot a trapped cow. The inciting incident for the connection of the contrasting stories of Mecha's children, their families and their servants occur when Mecha trips and cuts herself on a shattered wine glass. Mecha's daughter - who rushes to the aid of her mother - has been lying in bed with the maid, Isabel whom Mecha accuses of stealing the sheets. This starts a subtle commentary about race and class. But ironically at the end of this sequence, it is only Isabel, the maid whom Mecha detests who can drive her safely to medical care. 
Throughout the script there is a comment on the cycle of corruption and dysfunction pervading Argentine society, mirroring their parents in this dysfunctional family, the children indulge in incestuous or unacceptable relationships with each other and the servants. For example, in the dark yet beautiful shower scene, Mecha's adult son washes the mud of the swamp from his sister's legs, and in others he is conducts an affair with his father's mistress. In a telling comment on the endless cycle of corruption and ineptitude that is the family's life, in the end it is the children who are frolicking around the swamp pool. Martel notes of her use of the family as the starting point for her script in La Ciénaga: 'The film depicts a society that has lost its traditions but which cannot afford the security that could make up for it' (Forster 2011: 3). She says: "All of the films are more or less memories. You know, family is like a swimming pool too. If you want to understand things that you see in the spread of social life, if you focus on the family, you can see it immediately. And the desire amongst the family members, it's closely linked to the gap between classes and to the social tendency to want social class closed, like a caste, while the gap between the classes get bigger" (Martel in Wisniewski 2009: 1).

\section{Anna Muylaert and Que Horas Ela Volta?}

Like La Ciénaga, Brazilian Anna Muylaert's Que Horas Ela Volta? [The Second Mother] is a film that tells a universal story centered around family. Que Horas Ela Volta? won several international awards, including the Special Jury Prize at the Sundance Film Festival and the Best Film Audience Award in the Panorama Section of the Berlin Film Festival.

In The Second Mother, the dysfunctional family as a microcosm for contemporary society is explored two-fold in the key character, the hard working housekeeper, Val. She is both "the second mother" to the children of the wealthy family who employ her, including, Fabhino, the son and also the absent mother to her own daughter, Jessica, whom she supports from afar by working in the city. The film investigates contemporary social change and highlights issues of class and inequality 
in Brazil by setting the film within familial confines and by showing that Val as "a 'family member' is in fact a migrant, poorer, and ultimately a servant" (Pinazza 2015).

In the script, the divide between the way Val's daughter expects to be treated by the family who employ Val and the way Val accepts her treatment as a maid is highlighted when Val's daughter, Jessica comes to live with her. Jessica represents the next generation who are not afraid to cross the social divide. Even though of humble origins like her mother, Jessica does not believe she has to accept the hierarchies imposed by society like her mother does. The script excerpt below illustrates this pivotal scene and the way the family represents a microcosm of the themes of class and prejudice prevalent in wider Brazilian society.

From: The Second Mother script:

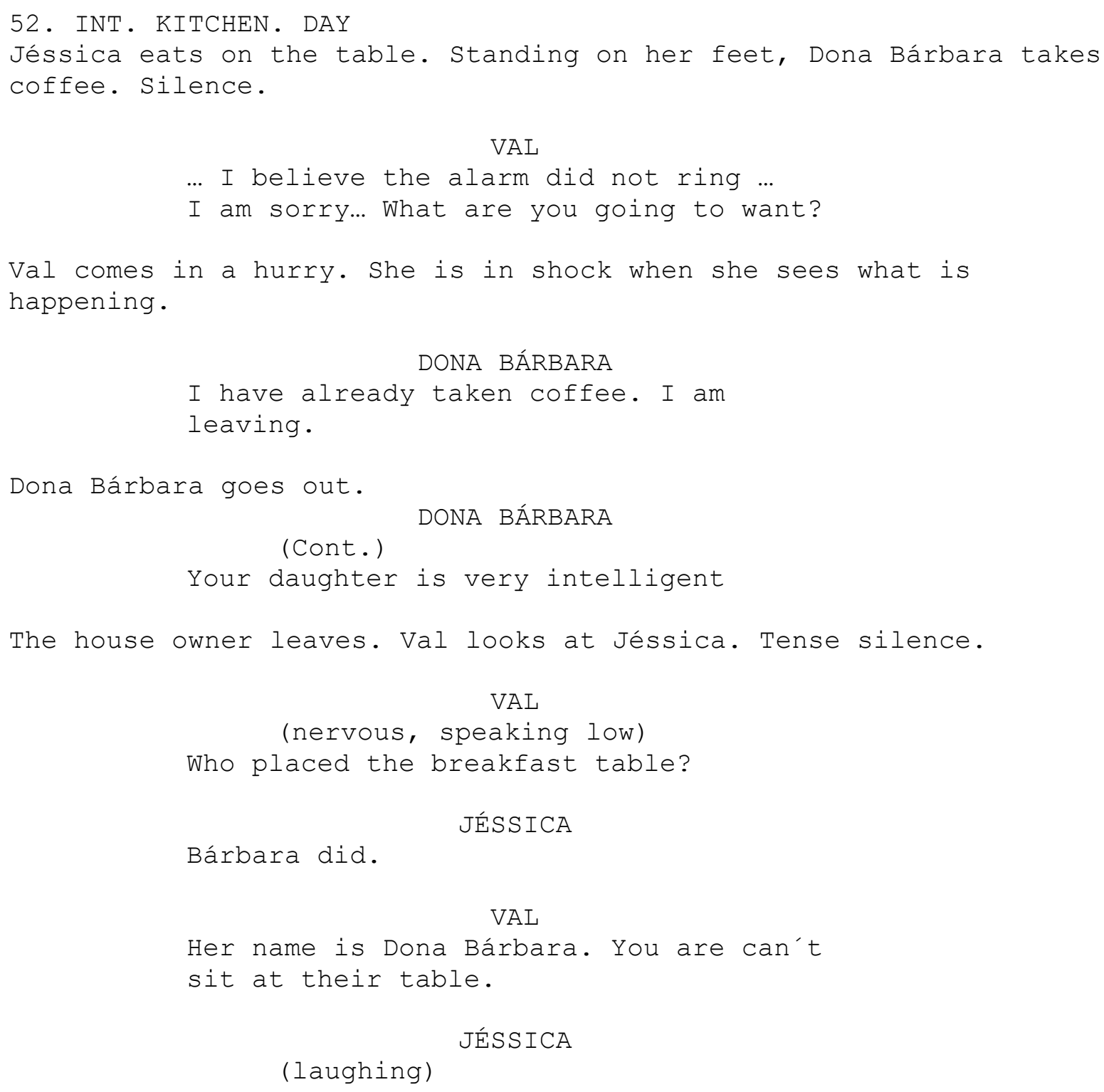




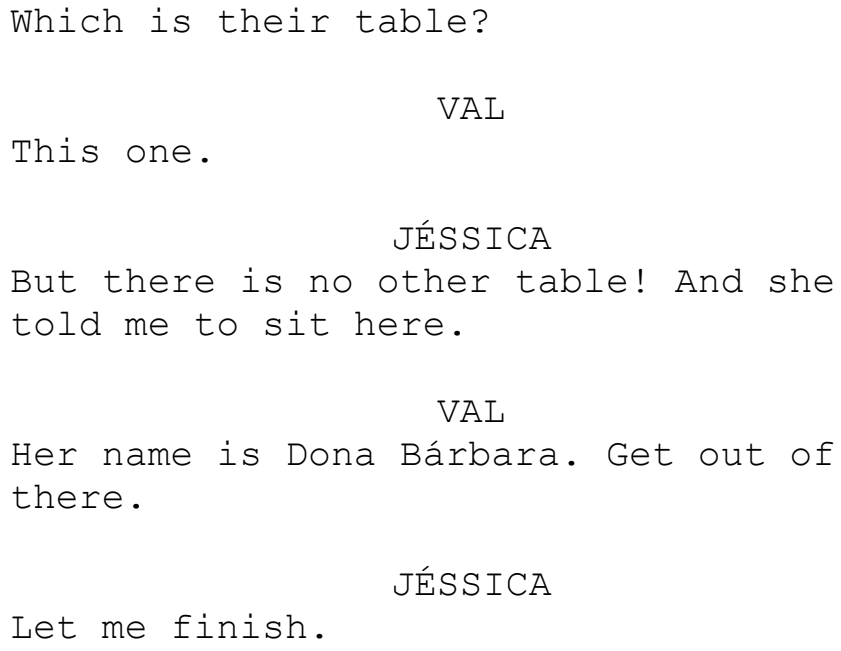

(Muylaert, 2019: position 2404 Kindle Edition)

This sequence is one of the key sequences symbolizing the difference between what is perceived as the role of the lower classes as represented by the peasant maid from the regions and the upper middle-class family who live in the main city of Brazil, São Paulo. While Val is submissive in this relationship, her daughter Jéssica wants to look at the world from the same point of view as the owners of the house. It is this conflict among the characters that is central to the script until the final resolution when Val finds a solution for her own crises. The film's ending provides hope for the future. As Pinazza (2015) notes:

Val's daughter both sanctions and rejects the social order that has kept her mother in a subservient role: she sits with the family and she is a good student, challenging preconceived notions of the underachievement of poorer classes. Val's daughter's refusal to 
align with upper-middle class conventions peaks in the sequence in which she jumps into the swimming pool, a powerful visual signifier of the boundaries between rich and poor, employer and servant. Val is, at first, ashamed by her daughter's boundary crossing, which starts to de-naturalize the demarcated spaces assigned to her. This process is illustrated when Val gets in the almost empty swimming pool for the first time after living in the house for many years.

In Que Horas Ela Volta? we can therefore see that via the universal story of a family and its fractured relationships, Muylaert has presented a dilemma facing Brazilian society. Most importantly, this includes the poverty which drives migrants like Val from the Northeast of the country to go to the cities of São Paulo and Rio de Janeiro to seek work.

\section{Claudia Llosa and La teta asustada}

The Peruvian filmmaker Claudia Llosa has made two films as a writer-director and is part of a new generation of Peruvian female filmmakers. Factors impacting the rise of women like Claudia Llosa in Peruvian cinema - this 'new' generation - include: 'a much higher level of technical training, with access to a more sophisticated set of equipment, benefactors and knowledge about funding schemes ... most have studied at post graduate level overseas ... they share an interest in developing their own personal vision and innovative style and focus on female characters from a range of classes, cultures and generations that otherwise tend to be neglected by most Peruvian feature cinema' and they 'have been supported by some of the most prestigious transnational funding schemes' (Barrow in Martin and Shaw 2017: 48-49).

In her chapter, "Through Female Eyes: Reframing Peru on Screen”, in Latin American Women Filmmakers Production, Politics, Poetics, Sarah Barrow discusses contemporary Peruvian female filmmaking and the common characteristics shared by stories by and about women. She discusses Robin and Jaffe's (1997) work in this area and notes that these common characteristics are 'a focus on ordinary women brought from the margins to the centre: a foregrounding of the "specificity of cultures, nations, local discourses, and critiques, within which these women's lives are enmeshed", a primary concern for the challenges of maternity as opposed to any conventional romantic storyline; and an emphasis on self-discovery as an ongoing process as well as part of community and family building' (Barrow in Martin and Shaw 2017: 49-50).

Llosa's distinctive use of national imagery and metaphor is also of interest in the development of the script. Her work focusses on the Andean region and both her films interrogate the social and regional inequalities of Peru. As Hausmann notes 'her movies deal with one of the traditional Latin 
American cultural topics, the conflict between civilization and barbarism, which she treats in an original way' (Hausmann in Maurer Queipo 2015: 83). Llosa's The Milk of Sorrow is a family story which tells the tale of Fausta (Magaly Solier), an Andean woman who puts a potato in her vagina so it would be physically impossible for someone to rape her. As White notes, she is a contemporary allegorical figure representing a violated Peru, 'A member of the next generation, Fausta is not simply an allegorical figure of a violated Peru. Making her body host to the food source native to Peru, she could be said to have a rhizomatic relationship with the nation' (White 2015: 192).

For this research it was not possible to access the script of The Milk of Sorrow. Although it was published in Colombia, by Editorial Norma, copies of that publication are not accessible in Brazil nor on-line. Nevertheless, we were able to find a video of lectures by Claudia Llosa in two events celebrating the release of the book of the script of The Milk of Sorrow. From these we were able to gain insights into the way Llosa as a screenwriter uses metaphor and develops the character of Fausta to explore the issues facing Peruvian society which she wishes to explore.

When I began the process of The Milk of Sorrow, I would go against any kind of positivism hopeful utopic that could impose itself as a priori. I would be the devil's advocate, because it seems to me as inconceivable to think about a happy ending. No, no, it was against my principles, of the person I was in that moment. But in that moment also I was in a process, a process similar to the one of Fausta, with all its instances that were clearly needing to heal (PUC Peru, 2010).

This sense of self-discovery is important in La Teta Asustada. We first see Fausta singing to her mother, Perpetua, on her deathbed. The film explores a number of issues that are to be resolved after the turbulence of Peru's contemporary history, which shows also the specificity of discourse on Peruvian society. Claudia Llosa grew up under Shining Path Conflict (Cendero Luminoso, 1980- 
2000) and the context of the film relates to the sexual atrocities against women by the dictatorship prior to the 1990 revolution. Llosa notes: 'I grew up in very different circumstances that the character of my film, but I did experience fear a lot of times. We were living in a difficult moment in my country during my youth, so I couldn't go to the cinema, for example, because it could explode from a bomb. I never experienced the cruelty that was experienced in the Andes [...] But I could grasp the feeling. There's something about the muteness of the culture [...] that I can relate to' (Llosa in Weinstein 2017:188).

Fausta rarely speaks and communicates by singing. The dyslexic Llosa notes 'I had a hard time as a kid, trying to communicate, trying to open myself. That was part of the challenge. But I needed to write my stories [...] But I was always finding my voice' (Llosa in Weinstein 2017: 189). The idea of the mute Fausta is one of the most striking of the script both narratively and metaphorically, indeed one of the plot drivers of the film is Fausta's silence and her song. As well as the metaphor of the silent and singing Fausta, the above-mentioned metaphor of the potato in Fausta's vagina and the metaphor of The Milk of Sorrow, the tainted breast milk which nourishes the child born of rape, are equally powerful metaphors that both serve to advance the narrative and conceptualize the theme of the legacy of Peru's past. As Llosa observes: "The movie remembers the traumas generated by violence and terrorism, and the need for those victims to heal. The singing works as a great vehicle to express, to recreate our memory or oblivion" (Llosa in Weinstein 2017: 187).

\section{Female screenwriting with a purpose - social change as a thematic choice}

In this article we propose that all the three female screenwriters in question are able to take to the world critical political situations in their countries because of their ability to write universal stories. It is, for all of them, also a source of inspiration to look at the position of those who suffer in their respective countries and tell their stories through a sensitive point of view. Muylaert explains that her inspiration comes from: 'life, the pains of life, the injustices of life - things that have been inspiring all writers of the world from centuries' (Muylaert, 2020 email to authors).

The perception of social and political critique can be seen in Claudia Llosa's The Milk of Sorrow. In the film we see the conflict between tradition and modernity in Peruvian society, and we are able to experience what that nation has been experiencing in the recent past. For around two decades, the country, particularly the countryside of Peru, was dominated by the actions of Sendero Luminoso which had the effect of keeping tourists out of the country and made rich families send their children abroad. Now that the actions of the group have been curtailed, Peruvian people face the 
challenge of dealing with modernity, visitors, and with a population that for many years suffered the fear and the threat of the Cendeiro Luminoso group which was famous for mistreating women. As Punté (2016) explains, The Milk of Sorrow deals with the acculturation of the Andean population. It is possible to perceive myths included in the plot. But there is one central thematic explored 'the violence of gender emerging in a patriarchal system, something that is present in all actual societies in a way that is more or less pressing' (Puente 2016: 94). As Vilchez states when analyzing The Milk of Sorrow:

In Peru, there has been no discussion about the thousands of soldiers and sailors who systematically raped during the internal armed conflict. The sinverguenzas [those without shame] forged during bloody acts of gang rape are not discussed in public discourse in Peru. This is indeed a troubling silence (Theidon, 2009: 405). [...] Llosa's film is subversive because we are shown the victim, but at the same time she makes a subversive claim that it should be placed within the agenda of history, memory, nation - a political agenda, related to projects of retribution and reconciliation. (Vilchez 2009: 29)

In considering Vilchez's quote, it is possible to think of Llosa's screenwriting as a political act. When talking to students of the university PUC of Peru about the release of her guion (script) in a published version, Llosa reaffirms this commitment to talk about Peruvian history: 'Commitment is one of the most important words that a filmmaker can have ... Of course, that I have as a person, an individual, I have a commitment with my culture, my country and with conjunctures that I have happened to experience ... Not as a mother, not as an individual, but of my professional life' (PUCP, 2010, video).

The Milk of Sorrow takes place in the poor areas of Lima. The main character, Fausta tries to organize her mother's funeral. She cannot take her mother back to be buried in her homeland, because the she has not enough money. Also, Fausta fears the legend "teta asustada", a curse passed from mother to children through maternal milk resulting from rape and abuse. This legend presents the situation faced by Peru during the 1980's and the 1990's. The film shows the friendship between Fausta and the gardener, with whom she can speak her rural dialect Quechua, a language 
which now only survives in the countryside. Therefore, in this story of a family who try to overcome the challenge of survival in a situation of difficult economic aspects, Llosa narrates different aspects of the pain that continues to trouble the population of her country.

In a lecture in 2017 at the Festival of Málaga, Llosa contended that she has 'a very strong need to decipher the most inaccessible corners of the soul'. And that the characters who interest her are the ones that 'symbolize or that concentrate the feelings, the contradictions of a moment'. (Llosa in LaVanguardia 2017). The Milk of Sorrow, from Llosa's point of view, managed to show a moment in which Peru 'begins to shine, to expand, to recover of a very hard time, and the move shows it in somehow'. It was a time of change when, as the movie shows, traditions and modernity were in conflict. 'The film talks about recovering our self-esteem'. In addition, the film generated a change in the Peruvian population's regard for films produced Peru. 'I believe that one of the things that I liked the most was that, being in a conversation with university students, many students came to me and one of them told me: thanks to you, now my mother lets me study cinema' (Llosa in LaVanguardia 2017).

Lucrecia Martel's La Ciénaga also considers social change. The film deals with the patriarchal society experienced by Argentinian families in the countryside, where women are left with no option but to obey their husbands. When the characters of Tali and Mecha are unable to travel for a longed weekend escape to Bolivia in order to buy school material for their children, the audience can see the unfair control that is exercised by their respective husbands Rafael and Gregorio who demand they do not make the trip. As Gómez notes, La Ciénaga 'offers us a reality without consolation or compensation' (2005: 79). As Martel explains the empathy for the suffering of others is in the bases of her creative process:

Let's say, where are ideas constituted? When are they established? How do we get to go to sleep when we know that half of humanity is suffering from it? When do we get used to it? ... So if we are a civilization capable of nullifying empathy with the other who is suffering, if we have that cultural ability to stop seeing the suffering of others, we are obliged to question the very bases of our perception. I do not think it is possible to achieve it completely, but every so often we are able to see something of the world. (Veas 2015)

In 2018, in an interview for the website Correspondencias Cine Y Pensamiento, Martel explained her vision of the possibility to take political positions through her scripts. 'Yes, sometimes one sees places where there are grave problems and realizes that the small transformation that can be done with a film is nothing when compared to the urgencies that exist' (Martel in Correspondencias Cine y Pensamiento 2018). But, for her, scripts are possibilities of making small changes: 'I say, talking 
about this world of a white middle class that has access to cinema, I think that there is a political possibility, slow, very slow, but that will have some effect' (Martel in Correspondencias Cine y Pensamiento 2018). As for the thematic that most interests her as a writer, Martel explains: 'To me the most interesting is cinema as an artifact that allows us to find cracks in reality; to remain with something that is very difficult to retain: the clear feeling that reality is a construction, an artifice [...] [which] allows us to refresh, allows us small moments of revelation' (Martel in Correspondencias Cine y Pensamiento 2018).

\section{How have these women made it on the world stage? Transnational funding imperatives}

Despite their different national situations, Martel, Muylaert and Llosa could be said to have a strong sense of purpose and belief in the importance of the stories they tell - they are not afraid to write stories by and about women regarding people on the margins. For example, while Muyalert notes that it has been historically difficult for women to compete for funding opportunities in a male dominated industry, this has not hindered her in telling the stories she wishes to tell. She notes that for her feature films, she has never encountered special funding support targeted at female screenwriters: 'In this sense, I always competed on the same way as men' (Muylaert, 2020 email to authors).

Martel, Muyalert and Llosa have taken advantage of the means available to them to bring their local stories to the world stage, including specific transnational Latin American funding programs to enable this. In a 2018 interview given on the website Mulheres no Cinema, Martel presents a strong point of view regarding the necessity for governments to invest in their national cinema via funding programs:

United States protect their industry, and have always done that in the case of cinema. We are blind if we think that the free market is free. The only way in which the national filmmakers can grow, get stronger and find their own paths is that governments take intelligent measures and create cultural politics. (2018: 6) 
Such government funding includes Program Ibermedia which was established in 1997 during the Iberoamerican Summit of Heads of State and Government (Cumbre Iberoamericano de Jefes de Estado y de Gobierno) to develop co-productions between Spain and Ibero-American countries and film festivals. Other examples include Brazilian incentives for cinema provided by Ancine (National Agency of Cinema) and festivals that support screenwriters, including the Sundance Festival, which has been important for the development of for example, Llosa's career trajectory with her first feature, Madeinusa (2006), Peru's official Oscar submission in that year (White 2015, p. 188), developed at the Sundance Writer's Workshop.

\section{Conclusion: South American female screenwriters - Telling women-centered stories}

Lucrecia Martel (Argentina), Anna Muylaert (Brazil) and Claudia Llosa (Peru) as this article has discussed, are women who via their storytelling explore the specific historical and cultural worlds of ordinary women and their families as a means of exploring contemporary social truths. As Punté notes the emergence of this contemporary generation of women filmmakers in Latin America has created a mark on the international stage via "right-to-the-point writing strategies" which draw from their storytelling traditions, by using relevant "metaphors and allegory" to bring to light the imperatives of their cultural and social history (Gamberini 2016: 1). In addition, Gamberini asks if there are different sensibilities that women bring to filmmaking, 'If a movie made by a woman is a more sensitive one?' (2016: 2). For that, she answers:

Many of these questions keep being asked, but what is really clear is that, in the cinema made by women, a persecution of the desire for the different, the female viewpoint of desire - as a narrative or aesthetical motor - is diverse... what exists is a different look at the cultural subjects, a particular rhythm, a way of looking at the different filmic material ... this full-of-desire way of looking incarnated by women. (Gamberini 2016: 2)

This observation is supported by Patricia Torres San Martín, in a 2014 paper regarding Latin American female filmmakers where she notes, it 'is no news to notice in the scripts of their films a feeling of social and political transgression centered as much in the emotional life as in the general convulsions that express their striving for an egalitarian identity' (2014: 2).

This article has shown that Martel, Muylaert and Llosa tell stories for local and global audiences with narratives that are locally specific yet universally relevant. The work of these female screenwriters takes to the world social issues that were previously only known in their own respective countries, from the female protagonist's point of view. All three of these female screenwriters explore the roles of women and children in families which have been traditionally dominated by the triple patriarchy of husband, father and state. They write scripts that use a 
dysfunctional familial environment where women are at the centre and where relationships are undermined by desperation, isolation, racial and social conflict, to explore the family in the context of the nation.

In this article we have explored how in the work of the Latin American female screenwriters Lucrecia Martel (Argentina), Anna Muylaert (Brazil) and Claudia Llosa (Peru). We have discussed the ways they have written women-centered scripts to reflect upon the social, cultural and political contexts that inspire their work and thus have developed stories that explore the universal grounded in the local family story. It is this truth that is explored via themes of manifest or latent familial, gender and sexual politics in the context of that nation's society, culture and history that drives the cinematic narratives of these three female screenwriters and has enabled them to make a mark on the world stage.

\section{References}

Arendt, H. (1998). "The Human Condition". Chicago: University of Chicago Press.

Barrow, S. (2017). “Through Female Eyes: Reframing Peru on Screen” in Martin, Deborah and Shaw, Deborah. 2017. Latin American Women Filmmakers Production, Politics, Poetics. New York: IB Taurus. pp. 48-70.

Brenes, CS., Cattryse, P. and McVeigh, M. (eds). 2017. Transcultural Screenwriting: Telling Stories for a Global World. Cambridge Scholars Publishing.

Correspondencias Cine y Pensamiento. (2018). "Laberinto en el oído: Entrevista a Lucrecia Martel". Dossier Sonorama. Número 5. México.

Retrieved from 
http://correspondenciascine.com/dossiers/05-sonorama/

Lim, D. (2018). "Film at Lincoln Center. La Ciénaga. Q\&A. Lucrecia Martel” [Video]. New York: Lincoln Center.

Retrieved from:

https://www.youtube.com/watch?v=sZC1vKmGQKs

Foster, G.A. (2011). "La Ciénaga". Senses of Cinema. Issue 60, Oct.

Retrieved from:

http://sensesofcinema.com/2011/cteq/la-cienaga/

Gómez, L. (2005). "El cine de Lucrecia Martel: La Medusa en lo recóndito". Ciberletras: Revísta de Crítica Literátia y de Cultura. Issue 13 (El cine hispanoamericano), July. pp. 85-93.

Dancyger, K. (2001). Global Scriptwriting Boston: Focal Press.

Gamberini, M. (2016). "La mujer en el cine latinoamericano: de minorías, miradas y cupos"

(Women in the Latin American cinema: of minorities, ways of looking and quotas). Retina Latina. $17^{\text {th }}$ of November of 2016.

Retrieved from

https://www.retinalatina.org/la-mujer-en-el-cine-latinoamericano-de-minorias-miradas-y-cupos/

Hausmann, M. "Claudia Llosa" in Maurer Queipo, I. (ed). (2012). Socio-critical Aspects in Latin American Cinema(s): Themes-Countries-Directors-Reviews. Frankfurt: Peter Lang.

LaVanguardia. (2017). "Claudia Llosa: creo en la capacidad sanadora del cine como cineaste y espectadora". La Vanguardia. Vida. Mar.

Retrieved from

https://www.lavanguardia.com/vida/20170323/421126817627/festival--claudia-llosa-creoen-la-capacidad-sanadora-del-cine-como-cineasta-y-espectadora.html

Llosa, C. (2009). La Teta Asustada (The Milk of Sorrow) 2009. DVD. Australia: The Match Factory. Analogue Titles. Distributed by Gryphon Entertainment. 
McVeigh, M. (2018). "Reading the Transnational: The Neo Gothic as Transnational Post-Feminist space in the films of Lucrecia Martel's La Ciénaga and Jane Campion's Sweetie". Critical Arts South North Cultural and Media Studies. Volume 31, 2017 - Issue 5: Cinema at the End of the World. Published online 2018. pp. 142-155.

McVeigh, M. (2017). "Screenwriting San Frontieres: The writing of a transnational film and the key factors impacting on the creation of story in the film co-production scenario" in Brenes, CS., Cattryse, P. and McVeigh, M. (eds) Transcultural Screenwriting: Telling Stories For a Global World. Newcastle upon Tyne: Cambridge Scholars Publishing. pp. 47-68.

Martel, L. (2001). La Cienaga. DVD. 2010. England: ICA Films.

Maurer Queipo, I. (ed). (2012). "Socio-critical Aspects in Latin American Cinema(s): ThemesCountries-Directors-Reviews". Frankfurt: Peter Lang.

Muylaert, Anna (2020), personal email communication to authors, March 30, 2020.

Muylaert, Anna (2019), organization of Belisa Figueiró and Rafael Sampaio. "Que horas ela volta?". São Paulo: Klaxon.

Page, J. (2009). "Crisis and Capitalism in Contemporary Argentine Cinema”. Durham and London: Duke University Press.

Pinazza, N. "Class and Gender in Muylaert's A que horas ela volta? and Mãe só há uma" Mediatico. Retrieved from http://reframe.sussex.ac.uk/mediatico 
PUC Peru (2010). "La teta asustada- Claudia Llosa presenta el libro-guion en la PUCP” [Video]. Lima: Cinencuentro.com. Retrieved from https:/www.youtube.com/watch?v=OBY tY5FKGQ

Punte, M. J. (2016). “A voz como espaço do desejo em Made in USA e La Teta Asustada”. Mostra de Cinema Mulheres em Cena. Rio de Janeiro: Ministério da Cultura. pp. 91-103.

Torres, P. (2014). “Cineastas de América Latina: desacatos de una práctica fílmica”. (Latin American Cinema Women: contempts of a filmic practice). Cinémas d'Amerique Latine. Femmes de cinéma, 22. 2014. p. 24-37. Retrieved from https://journals.openedition.org/cinelatino/747

Veas, P. (2015). “Lucrecia Martel. laFuga.”.

Vilchez, J. A. (2014) The body, the abject and Horror in Claudia Llosa's La Teta Asustada. Central European University. Department of Gender Studies.

Weinstein, A. (ed). (2017). "Writing from Personal Experience: A Strategy of Forward Motion. An interview with Claudia Llosa" in Weinstein Anna (ed). 2017. Writing for the Screen. New York and London: Routledge, Taylor and Francis. pp 185-189.

White, Patricia. (2015). Women's Cinema, World Cinema Projecting Contemporary Feminisms. Durhan and London: Duke University Press.

Wisniewski, C. (2009). “An interview with Lucrecia Martel”, August 17, 2009. Reverse Shot. Retrieved from http://reverseshot.org/interviews/entry/938/interview_lucrecia_martel

Yeates, H. M. McVeigh, and T. Van Hemert. 2011. "From Ethnocentrism to Transculturalism: a Globalised Pedagogical Journey”. Cultural Studies Review, Vol 17 Number 2 September 2011. 71-99.

Retrieved from

http://epress.lib.uts.edu.au/journals/index.php/csrj/article/viewFile/2008/2484

\section{Author biographies}


Dr Margaret McVeigh is Head, Screenwriting and Contextual Studies, Griffith Film School, Griffith University. She is a member of the SRN (Screenwriting Research Network International) Executive. Margaret holds a Masters of Screenwriting by Creative Practice and a PhD in Film and New Media Narrative. She has extensive national and international industry experience in Public Relations and Post-Production and has worked as the Commissioning Editor for Wiley publishers and as a Writer for the Australian National Broadcaster's ABC Splash. Margaret and is co-editor of Transcultural Screenwriting: Telling Stories for a Global World (2017). Her chapter, Work in Progress: The Writing of Shortchanged in The Palgrave Handbook of Screen Production (2019), explores her creative process in writing a feature film, development-funded by Screen Queensland.

Clarissa Mazon Miranda received her PhD in Letters at the Universidade Federal de Santa Maria (Brazil) in 2018. Her PhD thesis explored the intersemiotic translation of novels into movie scripts. She also holds a Master in Midiatic Communication from the same institution (2012) and a Bachelor of Journalism from the Universidade Federal de Santa Catarina (2005). Clarissa has completed several short courses in screenwriting. She works as a lecturer for Antonio Meneghetti Faculdade; as Marketing and International Affairs assistant for Fundação Antonio Meneghetti; as a journalist for the magazine Performance Lider; as Cultural Manager for the Recanto Maestro Youth Orchestra; and as a free-lancer screenwriter.

\section{Contact details}

Margaret McVeigh:

Griffith Film School, Griffith University, South Bank Campus, 226 Grey St, South Brisbane, Queensland 4101, Australia

E-mail: m.mcveigh@griffith.edu.au

ORCID: https://orcid.org/0000-0002-8307-3939 
Clarissa Mazon Miranda:

Antonio Meneghetti Faculdade (Antonio Meneghetti College), Estr. Recanto Maestro, 338,

Restinga Seca - RS, 97200-000

E-mail: miranda.clarissa@gmail.com

ORCID: https://orcid.org/0000-0003-2323-112X 